\title{
Nitrogen transfer between herbivores and their forage species
}

\author{
Sofie Sjögersten • Dries P. J. Kuijper • \\ René van der Wal • Maarten J. J. E. Loonen • \\ Ad H. L. Huiskes · Sarah J. Woodin
}

Received: 6 December 2009/Revised: 18 February 2010/Accepted: 26 April 2010/Published online: 22 May 2010

(C) The Author(s) 2010. This article is published with open access at Springerlink.com

\begin{abstract}
Herbivores may increase the productivity of forage plants; however, this depends on the return of nutrients from faeces to the forage plants. The aim of this study was to test if nitrogen $(\mathrm{N})$ from faeces is available to forage plants and whether the return of nutrients differs between plant species using ${ }^{15} \mathrm{~N}$ natural abundance in faeces and plant tissue. To investigate the effect of grazing on $\mathrm{N}$ transfer, we carried out a grazing experiment in wet and mesic tundra on high Arctic Spitsbergen using barnacle
\end{abstract}

S. Sjögersten $(\bowtie)$

School of Biosciences, University of Nottingham,

University Park, Nottingham NG7 2RD, UK

e-mail: sofie.sjogersten@nottingham.ac.uk

D. P. J. Kuijper - M. J. J. E. Loonen

Arctic Centre, University of Groningen, P. O. Box 716,

9700 AS Groningen, The Netherlands

D. P. J. Kuijper

Animal Ecology Group, University of Groningen,

P. O. Box 14, 9750 AA Haren, The Netherlands

D. P. J. Kuijper

Mammal Research Institute, Polish Academy of Sciences,

ul. Waszkiewicza 1c, 17-230 Białowieża, Poland

R. van der Wal

Aberdeen Centre for Environmental Sustainability (ACES), School of Biological Sciences, University of Aberdeen, Auris, 23 St. Machar Drive, Aberdeen AB24 3UU, UK

A. H. L. Huiskes

NIOO-KNAW, Centre for Estuarine and Marine Ecology, P.O. Box 140, 4400 AC Yerseke, The Netherlands

\section{S. J. Woodin}

Institute of Biological and Environmental Sciences, University of Aberdeen, Cruickshank Building, St Machar Drive,

Aberdeen AB24 3UU, UK geese (Branta leucopsis) as the model herbivore. $\mathrm{N}$ inputs (from faeces) increased with grazing pressure at both the wet and mesic sites, with the greatest $\mathrm{N}$ input from faeces at the wet site. The $\delta^{15} \mathrm{~N}$ ratio in plant tissue from grazed plots was enriched in mosses and the dwarf shrub species, reflecting the $\delta^{15} \mathrm{~N}$ signature of faeces-derived $\mathrm{N}$, but no such pattern was observed in the dominant grasses. This study demonstrates that the $\delta^{15} \mathrm{~N}$ signature of faeces and forage species is a useful tool to explore how grazing impacts on $\mathrm{N}$ acquisition. Our findings suggest that plant species which acquire their $\mathrm{N}$ close to the soil surface (e.g. mosses) access more of the $\mathrm{N}$ from faeces than species with deeper root systems (e.g. grasses) suggesting a transfer of $\mathrm{N}$ from the preferred forage species to the mosses and dwarf shrubs, which are less preferred by the geese. In conclusion, the moss layer appears to disrupt the nitrogen return from herbivores to their forage species.

Keywords $\delta^{15} \mathrm{~N} \cdot$ Arctic $\cdot$ Forage species $\cdot$ Geese . Herbivory $\cdot$ Moss $\cdot$ Nitrogen $\cdot$ Nutrients ·

Trophic interactions $\cdot$ Tundra $\cdot$ Vegetation $\cdot$ Faeces

\section{Introduction}

As predicted by the 'grazing optimisation hypothesis', herbivores can optimise their food intake by visiting previously grazed patches (Prins et al. 1980; McNaughton 1984; Drent and Van der Wal 1999). Critical to the development of such a relationship between herbivores and their food plants is the rate of nutrient recycling (DeAngelis 1992; Van der Wal and Hessen 2009), notably the short-circuiting of the litter production cycle and the return of animal excreta which are readily decomposable and high in labile nutrients (Floate 1970; Bazely and Jefferies 1985). Indeed, a stimulatory 
effect of urine and faeces has been shown on plant production in low nutrient environments such as the Arctic (Bazely and Jefferies 1985; Van der Wal et al. 2004).

Arctic tundra currently supports substantial populations of vertebrate herbivores, with geese being one of the most abundant in many regions (Van der Wal 2005). Arctic breeding geese can control both vegetation structure and cycling of nutrients in tundra ecosystems (Kerbes et al. 1990). The capacity of arctic tundra to support the growing numbers of geese breeding in the Arctic (Jensen et al. 2008; Wisz et al. 2008) will be affected by how these ecosystems respond to climate change as well as their intrinsic response to increased herbivory.

Nitrogen $(\mathrm{N})$ is generally considered the most limiting nutrient in arctic ecosystems, and $\mathrm{N}$ availability is known to modulate ecosystem response to herbivory (Bazely and Jefferies 1986; Olff and Ritchie 1998). The growing number of arctic breeding geese might impact on the functioning of arctic ecosystems through, for example, their effects on nutrient turn-over and $\mathrm{N}$ availability for plant growth.

Ultimately, the $\mathrm{N}$ balance of the tundra ecosystem is controlled by $\mathrm{N}$ inputs through $\mathrm{N}$ fixation and the decomposition of litter and soil organic material, but nutrient cycling is also directly controlled by herbivory. Vertebrate herbivory accelerates nutrient cycling directly by shortcutting the decomposition process (Stark and Grellmann 2002; Zacheis et al. 2002; Olofsson et al. 2004; Van der Wal et al. 2004) and indirectly by altering soil temperature and moisture (Zimov et al. 1995; Van der Wal and Brooker 2004; Gornall et al. 2007). On the one hand, low levels of grazing may result in increased net primary production compared to a situation without herbivores (McNaughton 1979; Hik and Jefferies 1990; Van der Graaf et al. 2005) that is sustained by higher nutrient availability resulting from faster nutrient turnover rates, largely due to the presence of animal excreta or through incorporation of litter into soil by trampling (Zacheis et al. 2002; Olofsson et al. 2004; Van der Wal et al. 2004). On the other hand, regrowth of key forage species can be curtailed under conditions of intensive grazing if nutrient return to these species is not sufficient (Gauthier et al. 1995) or non-forage species act as a sink for nutrients. Geese are highly selective to foragers choosing plant species that give the greatest nutritional return, commonly graminoids and forbs (Cadieux et al. 2005; Audet et al. 2007). It is therefore possible that goose grazing will reallocate $\mathrm{N}$ from the preferred forage species to the less preferred forage species if these are able to effectively access faecal $\mathrm{N}$.

Due to the interactions between $\mathrm{N}$ cycling and goose grazing, tracing the fluxes of $\mathrm{N}$ between vegetation, geese and the soil is crucial to understanding the $\mathrm{N}$ economy of the vegetation. Natural abundance of ${ }^{15} \mathrm{~N}$ can be used to investigate cycling of $\mathrm{N}$ due to differential $\delta^{15} \mathrm{~N}$ ratios amongst plant species and their herbivores (Hwang et al. 2007; Varo and Amat 2008). The $\delta^{15} \mathrm{~N}$ signal of faeces is enriched due to the preferential loss of ${ }^{14} \mathrm{~N}$ during volatilisation of $\mathrm{NH}_{3}$ (Wada et al. 1981). Furthermore, it is likely that the $\delta^{15} \mathrm{~N}$ signal of faeces to some extent reflects that of the forage species.

In this study, we investigate the potential to use the enriched ${ }^{15} \mathrm{~N}$ signal in faeces as a natural tracer to investigate the fate (e.g. uptake by plants) of $\mathrm{N}$ originating from goose faeces. The aim of this study was to determine the effects of goose faeces on the nitrogen economy of tundra plants in two widespread and important goose habitats: mesic heath and wet moss meadow. For this, a field experiment with grazing treatments over 3 years was used. The following specific hypotheses were tested: (1) Plant uptake of $\mathrm{N}$ from goose faeces can be traced through $\delta^{15} \mathrm{~N}$ enrichment of the plant material (2) Mosses have greater access to $\mathrm{N}$ from goose faeces than vascular plants, (3) The faecal $\delta^{15} \mathrm{~N}$ enrichment is modulated by the dominant forage species in the herbivores diet. To our knowledge, this is the first time the transfer of $\mathrm{N}$ from herbivore inputs to the vegetation using stable isotopes is studied in a realistic field-scale grazing experiment.

\section{Materials and methods}

\section{Site descriptions}

This research was carried out in Adventdalen on high arctic Spitsbergen, Norway. Adventdalen, a valley in south central Spitsbergen, Norway $\left(78^{\circ} 10^{\prime} \mathrm{N}, 16^{\circ} 06^{\prime} \mathrm{E}\right)$ has very low numbers of breeding pink-footed geese (Anser brachyrhynchus) and barnacle geese (Branta leucopsis). The valley is mainly utilised by geese during spring and autumn migration. The mean annual temperatures are $-6.7^{\circ} \mathrm{C}$, the January mean temperature is $-15.3^{\circ} \mathrm{C}$ and the July mean temperature is $5.8^{\circ} \mathrm{C}$, reflecting the oceanic climate in the area; the mean annual precipitation is $180 \mathrm{~mm}$ (1961-1990 averages, NOAA Global Climate Normals). Landscapes are underlain by permafrost; the maximum depth of thaw (in August) reaches $50-70 \mathrm{~cm}$ in mesic areas and ca $50 \mathrm{~cm}$ in wetter areas.

The study used a mesic site and a wet site for the experimental work. Vegetation at the mesic site is dominated by Salix polaris ( $51 \%$ cover) and Alopecurus borealis, with some Luzula confusa (graminoids $26 \%$ cover) and Bistorta vivipara (less than $4.8 \%$ cover). The $2.1 \pm 0.2 \mathrm{~cm}$ deep moss mat is composed of Tomentypnum nitens, Hylocomnium splendens and Sanionia uncinata (89\% cover) 
providing nearly continuous ground cover. At the wet site, the dominant moss is Calliergon richardsoni which forms a continuous layer of $6.1 \pm 0.4 \mathrm{~cm}$ depth. The most abundant vascular plants are the grasses Dupontia spp. and Calamagrostis stricta, contributing ca. 53\% to ground cover. Other species include Equisetum arvense (9\% cover) and some forbs e.g. Cardamine nymanii. The cover estimates are based on data from control plots measured at peak biomass at the start of the experiment in 2003.

\section{Experimental design}

\section{Grazing experiment}

To investigate the effects of grazing on $\mathrm{N}$ cycling, we carried out a grazing experiment in these two habitats, and the experiment also included a climate warming component. The experiment consisted of ten blocks (five each site) with each block containing six treatments ( 30 plots in total at each site). The experiment was a fully factorial randomised block design. The grazing treatments were no, low and high levels of grazing, the climate warming experiment included ambient and warmed plots (see Sjögersten et al. (2008) for more detail). In this paper, we specifically focus on the grazing treatments. This approach was chosen since the warming treatment had very limited effect on ground surface temperatures at the wetter site, and no increase in total plant biomass was detected in warmed plots after 3 years (Sjögersten et al. 2008). Furthermore, there were no significant effects or trends linked to the warming treatment with respect to the ${ }^{15} \mathrm{~N}$ signal in either the vegetation or the faeces.

The grazing treatments were carried out during the growing seasons of 2003, 2004 and 2005 using pairs of adult wild captured barnacle geese in cages. These grazing treatments, (a pair of adult geese being placed on a $2 \times 2 \mathrm{~m}$ plot for either 0,1 or $5 \mathrm{~h}$ ) were applied twice over the growing season, in early July and in early August, apart from the last season when only the early July grazing event was carried out. The average total time spent foraging (by two geese, averaged over the 2003 and 2004 grazing events) at the mesic site was 18 and $56 \mathrm{~min} \mathrm{~m}^{-2}$ year $^{-1}$ in the low- and high-grazing treatments, respectively, and 30 and $127 \mathrm{~min} \mathrm{~m}^{-2}$ year $^{-1}$ at the wet site. The greater amount of time spent grazing at the wet than at the mesic site reflects the natural grazing preference of geese for wet tundra habitat. After 3 years, there was no significant effect of grazing on soil temperature $(P>0.5)$ at either site. Due to the compaction of the moss mat by geese, the volumetric moisture content was increased from $0.70 \pm 0.01$ to $0.98 \pm 0.01 \mathrm{~m}_{\text {water }}^{3} \mathrm{~m}_{\text {soil }}^{-3}(\mathrm{SE}$ shown) at the wet site. At the mesic site, the impact of the geese on soil moisture was negligible.
Diet analysis

To explore if there was a relationship between the diet and the $\delta^{15} \mathrm{~N}$ ratio of goose faeces, we determined diet composition. To achieve this, 5-7 faeces were collected from each plot (20 grazed plots in each habitat) following each of the experimental grazing events (200 samples in total). The samples were analysed microscopically and the diet was determined based on plant specific epidermal fragments. Water was added to a small amount of homogenised dropping material. Ten slides per sample were created and 10 plant epidermal fragments identified per slide. Plant species were determined by comparing epidermal fragments to a reference collection made of plant material collected close to the experimental plots. Epidermal fragments closest to the centre of the microscopic field were identified. The next fragment was found by moving the field $2 \mathrm{~mm}$ to the left and $2 \mathrm{~mm}$ to the top of the slides. This resulted in 100 randomly identified plant fragments per sample.

To ensure that the material in the droppings originated from the experimental plots, before and after each grazing event the cages with the geese were placed for $2 \mathrm{~h}$ on a wooden board to stop cross-plot contamination. As nonbreeding barnacle geese have an average retention time of $2 \mathrm{~h}$ (Prop et al. 1984) and as geese were starved prior to grazing (on the board), faeces samples originated from food grazed at experimental plots. Remaining faeces were put back on experimental plots they originated from (for more details see Kuijper et al. 2009).

\section{$\mathrm{N}$ input from faeces from experimental grazing}

The dropping input to the vegetation was quantified by counting the number of faeces per plot during experimental grazing, and during the $2 \mathrm{~h}$, geese were on the wooden board following grazing. A mixed sample of five faeces was collected from each plot that was grazed for $5 \mathrm{~h}$. A similar sample was collected during $2 \mathrm{~h}$ following the $1-\mathrm{h}$ experimental grazing.

The samples were oven-dried directly after collection at $60^{\circ} \mathrm{C}$ for $48 \mathrm{~h}$, and total $\mathrm{N}$ was determined by means of automated elemental analysis (Interscience EA 1110). Nitrogen input per plot was calculated by multiplying the number of faeces by the average dry weight of faeces (0.49 $\mathrm{g} \pm \mathrm{SE} 0.27)$, based on 100 samples collected in 2003 , and multiplying by total $\mathrm{N}$ concentration. Total $\mathrm{N}$ input was averaged for the three consecutive years.

Sampling and analysis of plant tissue and faeces for $\delta^{15} \mathrm{~N}$ ratios

${ }^{15} \mathrm{~N}$ content in goose faeces was determined to provide information on the enrichment of ${ }^{15} \mathrm{~N}$ in the faeces and on 
how diet selection impacts on the ${ }^{15} \mathrm{~N}$ signal in faeces relative to ${ }^{15} \mathrm{~N}$ content of the plant species present. The first grazing event was chosen for this, as there was no possible ${ }^{15} \mathrm{~N}$ enrichment of experimental goose grazing on plants at this point. The $\delta^{15} \mathrm{~N}$ ratio in the droppings is a composite measure of the $\delta^{15} \mathrm{~N}$ ratio of unmodified plant material ingested by the geese and of more soluble $\mathrm{N}$ that has undergone metabolic transformation within the goose body. A positive $\delta^{15} \mathrm{~N}$ ratio indicates ${ }^{15} \mathrm{~N}$ enrichment compared to a reference standard (atmospheric nitrogen), whilst a negative ratio represents depletion of ${ }^{15} \mathrm{~N}$ relative to the reference standard. We compared these values to $\delta^{15} \mathrm{~N}$ ratios of plant samples collected from the control plots.

To determine whether species of tundra plants differ in their use of faecal $\mathrm{N}$ and how grazing affects plants $\delta^{15} \mathrm{~N}$ ratio after 2 years of grazing, we analysed the $\delta^{15} \mathrm{~N}$ ratio of the dominant moss and grass species at the mesic and wet site, i.e. Alopecurus borealis, Tomentypnum nitens at the mesic site and Dupontia spp. and Calliergon richardsoni at the wet site. We also analysed Salix polaris from the mesic site where it was by far the most abundant vascular plant. These species were present in all plots even after grazing, enabling a comparison of $\delta^{15} \mathrm{~N}$ natural abundance ratios in plant tissue between treatments. For brevity these species as subsequently denoted Alopecurus, Tomentypnum, Dupontia, Calliergon and Salix. Green above-ground tissue of these species was sampled; specifically, we collected only the most recently formed leaves and the green surface part of the moss mat both in grazed and ungrazed plots. For the grasses, Salix and Calliergon new leaves (i.e. formed after the grazing event) were collected. The samples were collected from three random locations within each plot in August (after the second grazing event) in 2004 and then again in 2005 to account for the spatial variability on the plot level given the small amount of sample that could be collected at each occasion (i.e. low amounts of grass regrowth in the high grazing treatment). To ensure no contamination from goose faeces of the plant tissue, we collected plant samples that were not in direct contact with faeces and the individual samples were inspected visually to ensure there were no traces of faeces on the tissue. At the mesic site, the risk of contamination was lower due to the generally lower input of faeces, also the faeces where mostly intact after the grazing event. More or less, complete removal of Bistorta vivipara (mesic site) and Equisetum arvense (wet site) (subsequently denoted Bistorta and Equisetum) by the geese during grazing meant that we could not sample these species from grazed plots. However, we subsequently did obtain replicate samples $(n=5)$ from control ungrazed plots of Bistorta tubers from the mesic experimental site and Equisetum shoots from the wet site for determination of tissue $\delta^{15} \mathrm{~N}$ ratio for comparison. Note that these two species were therefore not included in the analysis of grazer impacts on the $\delta^{15} \mathrm{~N}$ ratio but only used to gain insights into how the $\delta^{15} \mathrm{~N}$ ratio varied between the forage species. All samples were dried at $70^{\circ} \mathrm{C}$, milled and analysed for ${ }^{15} \mathrm{~N}$ content. The $\mathrm{N}$ isotopic composition was determined using a Fisons NA-1500 element analyser coupled on line via a Finnigan conflo II interface, to a Finnigan MAT Delta $\mathrm{S}$ isotope ratio mass spectrometer (IRMS).

\section{Data analysis}

Data were analysed in GENSTAT V10. Significant differences between plant species $\delta^{15} \mathrm{~N}$ ratio and between plants and faeces were analysed using ANOVA, and significant differences between means were tested with a post hoc Tukey's HSD at 95\% confidence). Generalised linear mixed models were used to test for treatment effects on the $\delta^{15} \mathrm{~N}$ ratio in plant tissue and faeces. These models used the method of residual maximum likelihood with 'block' as a random effect and grazing as the fixed effect. Plant tissue $\delta^{15} \mathrm{~N}$ ratio data were pooled between ambient and warmed plots for each grazing treatment, and also over 2004 and 2005 prior to analysis (except for Bistorta and Equisetum which were sampled from control plots in one year only). One outlier was removed from the Tomentypnum data set due to an anomalously high $\delta^{15} \mathrm{~N}$ ratio (possibly due to high activity of cyanobacteria in the moss tissue or an alternative strong source of $\mathrm{N}$ ).

A one-way ANOVA was used to test for the effect of grazing (low vs. high) on the proportion of a plant species (group) in the diet. Diet samples from ambient and warmed plots per grazing treatment were averaged per block. Percentage data were arc-sin $\sqrt{ }$ transformed prior to analyses. The diet composition in 2003 and 2005 did not differ statistically from 2004 (see Kuijper et al. 2009). In the present study, diet data are shown from the second grazing event in 2004, which corresponds to the time period then the plant tissue samples were collected.

\section{Results}

Goose faecal N inputs over the period 2003-2005 to the mesic site were estimated as $0.29 \pm 0.03$ and $0.41 \pm$ $0.04 \mathrm{~g} \mathrm{~N} \mathrm{~m}^{-2}$ year $^{-1}$ in the low- and high-grazing treatments, respectively, and to the wet site as $0.51 \pm 0.03$ and $0.70 \pm 0.07 \mathrm{~g} \mathrm{~N} \mathrm{~m}^{-2}$ year $^{-1}$ (SE shown). $\mathrm{N}$ input increased significantly with grazing duration (mesic site $F_{1,19}=16.31, P<0.05$; wet site $\left.F_{1,19}=10.47, P<0.05\right)$ and was greater in the wet than in the mesic site $\left(F_{1,40}=32.86, P<0.0001\right)$ due to the greater time spent foraging and consequently higher production of faeces at the wet site. 
The plant tissue $\delta^{15} \mathrm{~N}$ ratio varied significantly between different species with Salix, Bistorta and the mosses having a $\delta^{15} \mathrm{~N}$ ratio significantly below zero, whilst the $\delta^{15} \mathrm{~N}$ ratio of the grasses was around zero, only Equisetum had a clearly enriched $\delta^{15} \mathrm{~N}$ ratio (Fig. 1a). The $\delta^{15} \mathrm{~N}$ in faeces was generally enriched compared to plant tissue $\left(F_{10,43}=54.45, P<0.001\right)$ (Fig. $1 \mathrm{~b}$ and $\left.\mathrm{c}\right)$. Although, the differences in the $\delta^{15} \mathrm{~N}$ ratios were less pronounced when comparing faeces with the two graminoid species than the difference between faeces and other study species (e.g. mosses and Salix), the difference between the means was significant $\left(P<0.05\right.$, Tukey's HSD); only the $\delta^{15} \mathrm{~N}$ ratio of Equisetum did not differ significantly from goose faeces.

Interestingly, the grazing experiment demonstrated that the $\delta^{15} \mathrm{~N}$ ratio cannot only be used as a tracer of $\mathrm{N}$ transfer from herbivores to the vegetation (within the constraints mentioned earlier), but also of $\mathrm{N}$ transfer from food plants to the herbivore. As goose diet shifted with duration of grazing (Fig. 2), so did the ${ }^{15} \mathrm{~N}$ concentration in faeces (Fig. 1b, c). At the mesic site, Alopecurus and Bistorta were the most important forage species for geese and moss (mainly Tomentypnum nitens) formed a lower proportion of the diet (Fig. 2). From 1 to $5 \mathrm{~h}$ of grazing at the mesic site, the proportion of Bistorta in the diet increased $\left(F_{1,9}=9.11\right.$, $P<0.05$ ) at the expense of Alopecurus (marginally significant $\left.F_{1,9}=4.95, P=0.057\right)$ whilst the proportion of moss remained unchanged ( $P>0.9$; Fig. 2). Since Bistorta is ${ }^{15} \mathrm{~N}$ depleted, and Alopecurus is slightly enriched (Fig. 1), the overall signal of the goose diet would have become more depleted over time, as is indeed reflected in the decrease in $\delta^{15} \mathrm{~N}$ ratio in the goose faeces after $5 \mathrm{~h}$ compared to $1 \mathrm{~h}$ of grazing (Fig. 1b). A similar pattern was observed at the wet site where the most important forage species were Equisetum, moss (mainly Calliergon richardsoni) and Dupontia (Fig. 2). After $5 \mathrm{~h}$ of grazing, the proportions in the diet of Dupontia and moss, which are both depleted in $\delta^{15} \mathrm{~N}$, increased $\left(F_{1,9}=5.84, P<0.05, F_{1,9}=5.82, P<0.05\right.$, respectively), whilst that of Equisetum, which is strongly $\delta^{15} \mathrm{~N}$ enriched, decreased $\left(F_{1,9}=23.32, \quad P=0.001\right.$; Figs. 1,2), resulting again in a decrease in $\delta^{15} \mathrm{~N}$ ratio of the goose faeces (Fig. 1c).

The vegetation $\delta^{15} \mathrm{~N}$ ratios in grazed plots reflected the elevated $\delta^{15} \mathrm{~N}$ ratio in goose faeces: the overall $\delta^{15} \mathrm{~N}$ ratio in plant tissue was increased by grazing (all species combined, $F_{2,57}=5.71, P=0.066$; note that Equisetum and Bistorta were not included in this analysis due to their nearly complete removal in grazed plots).

The $\delta^{15} \mathrm{~N}$ ratio of some functional groups appeared to respond more clearly to the grazing treatment than others (Fig. 3). For the mosses and the dwarf shrub (Salix), the grazing effect was clearly demonstrable $\left(F_{2,18}=5.62\right.$, $P<0.05$ and $F_{2,8}=4.17, \quad P=0.057$, respectively; Fig. 3a, d and c). In contrast, there was no significant grazing effect $\left(F_{2,18}=0.02, \quad P=0.98\right)$ for grasses (Fig. 3b, d). (a) Plant tissue $\delta^{15} \mathrm{~N}$ ratio

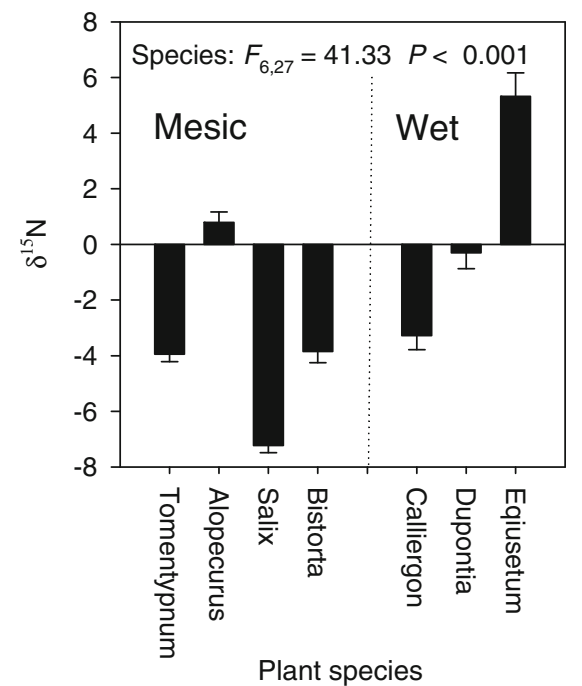

(b) $\delta^{15} \mathrm{~N}$ ratio in faeces, mesic site

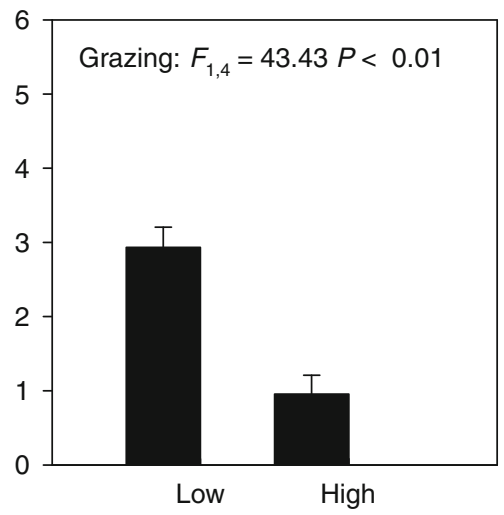

Grazing (c) $\delta^{15} \mathrm{~N}$ ratio in faeces, wet site

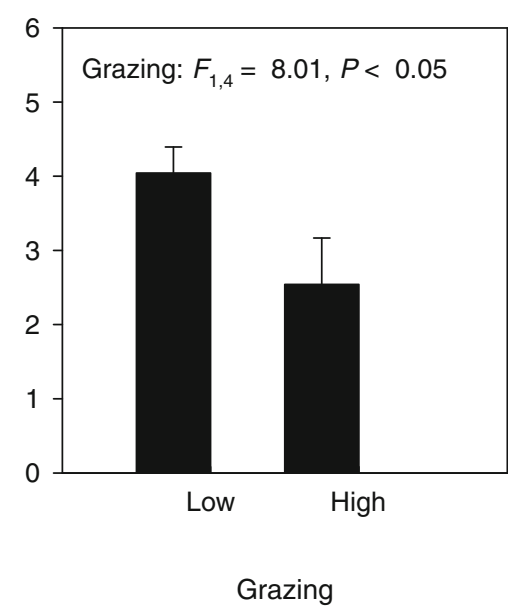

Fig. 1 a $\delta^{15} \mathrm{~N}$ ratio (\%) in the dominant plant species of each functional plant group present in the experimental plots. The values are from ungrazed control plots at the mesic site (Tomentypnum nitens (moss), Alopecurus borealis (grass), Salix polaris (dwarf shrub), and Bistorta vivipara (forb)) and at the wet site (Dupontia spp. (grass), Calliergon richardsonii (moss), and Equisetum arvense (horsetail)), b $\delta^{15} \mathrm{~N}$ ratio (\%o) in goose faeces collected directly after the first grazing event in 2003 at the mesic site (low and high grazing represent 18 and $56 \mathrm{~min}^{-1}$ year ${ }^{-\mathrm{r}}$ of grazing, respectively, at this site) and $\mathbf{c}$ the wet site (low and high grazing represent 30 and $127 \mathrm{~min}^{-1}$ year $^{-\mathrm{r}}$ of grazing, respectively, at this site); means, SE and significant main effects are reported in the figure 
Fig. 2 Diet composition (i.e. proportion in diet) of geese during the second grazing of the plots in 2004 at a the mesic and b the wet tundra sites on lowand high-grazing plots. The three species that made up the majority of the diet at each site are shown individually, whilst the small proportion of other species consumed where combined into 'other' monocots and dicots

Fig. 3 Impact of the grazing treatment on green plant tissue $\delta^{15} \mathrm{~N}$ ratios (\%o) of the target species at the mesic site:

a Tomentypnum nitens,

b Alopecurus borealis, c Salix polaris, and the wet site:

d Calliergon richardsoni, and e Dupontia sp, means and SE are shown (data from 2004 to 2005 combined), $n=5$ (a) Mesic site

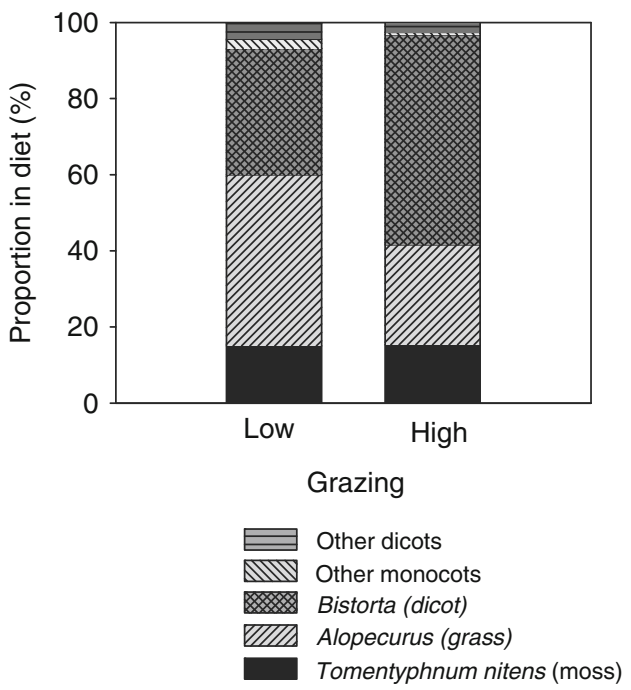

(b) Wet site

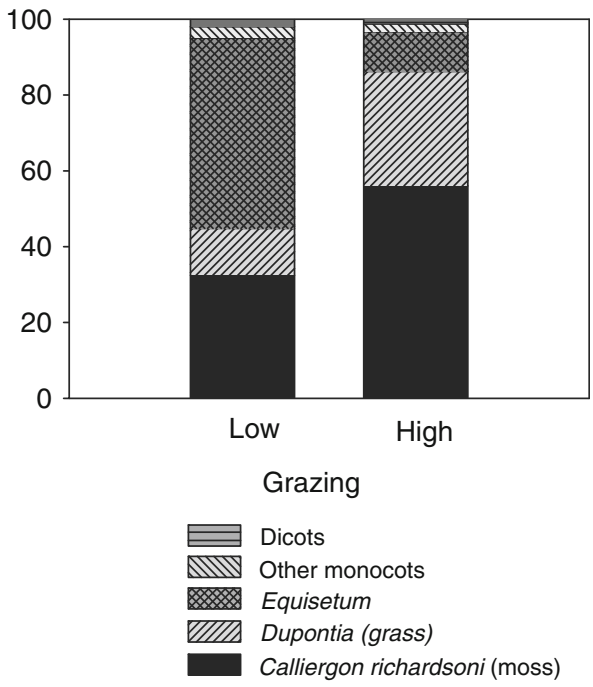

Mesic site

(a) Tomentypnum

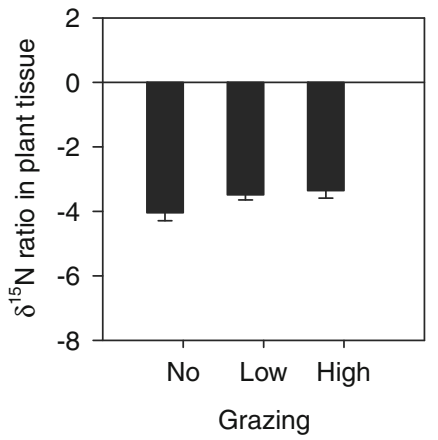

Wet site

(d) Calliergon

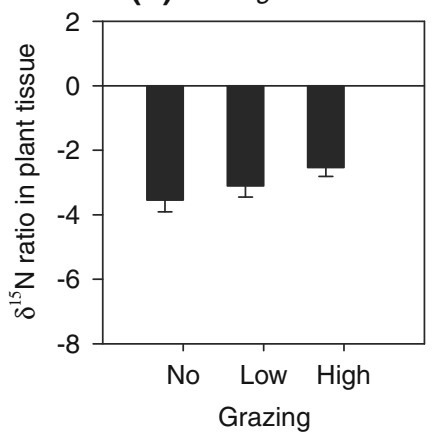

(b) Alopecurus

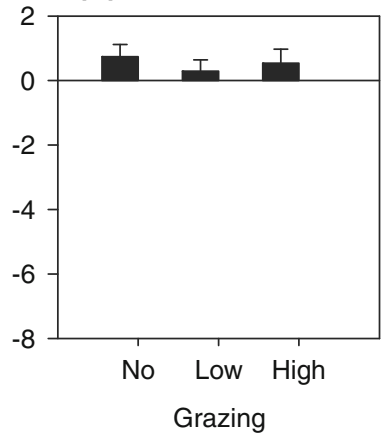

(e) Dupontia

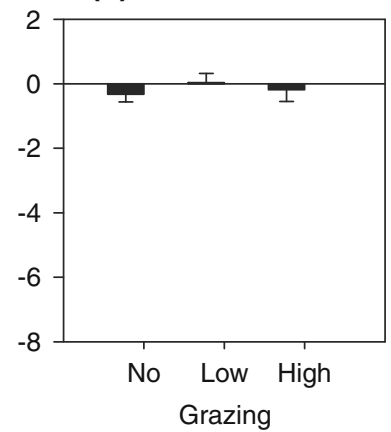

(c) Salix

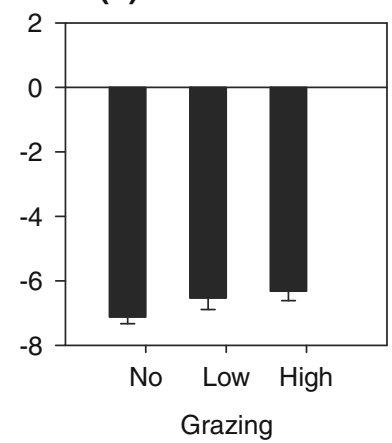

\section{Discussion}

Generally, the shallow rooted vascular species and the mosses had negative $\delta^{15} \mathrm{~N}$ ratios whilst the grasses, which have roots that penetrate more deeply into the soil, and indeed the very deep rooting Equisetum (Marsh et al. 2000), had a more enriched $\delta^{15} \mathrm{~N}$ ratio. This may indicate an alternative source of $\mathrm{N}$ compared to the Salix, Bistorta and mosses, such as $\mathrm{N}$ mineralised from old organic matter deeper down in the soil profile, which tend to have a more enriched $\delta^{15} \mathrm{~N}$ ratio (Kramer et al. 2003; Billings and Richter 2006).

Our findings show that a faecal $\mathrm{N}$ signal can be detected in the mosses and Salix but not in the grasses. This can be 
interpreted in two ways (1) the ${ }^{15} \mathrm{~N}$ gradient between faeces and plant tissue is not sufficient to detect an experimental faecal $\mathrm{N}$ signal in grass tissue either in response to the ${ }^{15} \mathrm{~N}$ signature of the $\mathrm{N}$ assimilated from the soil or previous enrichment of grass tissue from grazers and (2) mosses and Salix has greater access to faecal N; we will now address these points in order. (1) There was not a sufficient difference in the $\delta^{15} \mathrm{~N}$ ratio between the grasses and the faeces to be detectable: The $\delta^{15} \mathrm{~N}$ ratio differed significantly between the two grass species and faeces, 2.2 and 4.4\% for Alopecurus and Dupontia, respectively. In previous studies investigating the transfer of $\mathrm{N}$ between trophic levels, relatively small differences in $\delta^{15} \mathrm{~N}$ ratios were found to be significant (e.g. $0.7 \%$ ) when tracing impacts of herbivores on plant tissue $\delta^{15} \mathrm{~N}$ ratios (Frank and Evans 1997). This suggests that the difference between faeces and grasses should be detectable if the faecal $\mathrm{N}$ reaches the grasses. With respect to the potential pre-existing enrichment of the $\delta^{15} \mathrm{~N}$ signature of the vegetation due to the presence of reindeer in the valley, the $\delta^{15} \mathrm{~N}$ ratios of the grass tissue in our control plots were not higher than those found in ungrazed sites (Frank and Evans 1997). Furthermore, reindeer use of the wet meadow in our study site is very rare so it is unlikely that reindeer will have impact on the initial ${ }^{15} \mathrm{~N}$ signature in Dupontia. We therefore think that it is unlikely that grass tissue $\delta^{15} \mathrm{~N}$ ratios were strongly affected by reindeer prior to the start of the experiment. (2) The mosses and Salix accessed the goose $\mathrm{N}$ to a greater extent than the grasses: Greater ranges in $\delta^{15} \mathrm{~N}$ ratios in mosses than grasses have been found in habitats close to seabird colonies, where faeces with high $\delta^{15} \mathrm{~N}$ ratios is deposited on the vegetation, suggesting that mosses have greater access to $\mathrm{N}$ from faeces than grasses (Lee et al. 2009). Furthermore, Frank and Evans (1997) found that the $\delta^{15} \mathrm{~N}$ ratio in grasses even dropped with grazing (which they linked to altered microbial metabolism of soil $\mathrm{N}$ and not direct impacts of faeces on plant tissue $\delta^{15} \mathrm{~N}$ ratios). Our interpretation of the experimental results is therefore that faecal $\mathrm{N}$ from herbivores is accessed to a greater extent by mosses and Salix than by grasses.

Differential access to faecal $\mathrm{N}$ for the different functional groups is likely to be driven by how they acquire their $\mathrm{N}$. We speculate that the pattern of access to faecal $\mathrm{N}$ shown here is an effect of rooting depth (Brooker and Van der Wal 2003): shallow rooting vascular plant species as well as mosses, which absorb their $\mathrm{N}$ directly through their leaves, have a greater access to faecal $\mathrm{N}$ than more deeply rooting species. Moss has previously been shown to effectively absorb nutrients and prevent further access of nutrients to vascular plants in boreal wetlands (Malmer et al. 2003), wet (Kotanen 2002) and mesic (Gornall et al. 2009) tundra, and to some extent also in dry high arctic heath (Tye et al. 2005). Hence, mosses may disrupt the $\mathrm{N}$ transfer between herbivores and their preferred forage species given that $\mathrm{N}$ from goose faeces is derived largely from vascular plants. Ultimately, the impact of low faecal $\mathrm{N}$ returns following grazing on regrowth of grasses will depend on the availability of $\mathrm{N}$ in the soil. Furthermore, removal of geese from tundra vegetations has been shown to reduce moss biomass and increase vascular biomass (Gauthier et al. 2004). This decline in moss biomass might partly be linked to the reduced transfer of $\mathrm{N}$ from the vascular plants to the moss via preferential grazing and $\mathrm{N}$ inputs to the mosses from faeces.

Nutrient inputs have been shown to be important for maintaining growth of goose forage species in sub-arctic salt marshes under moderate grazing intensities (Bazely and Jefferies 1985; Ngai and Jefferies 2004). Thus, the lack of N return to grasses that we have seen in our study might result in a depletion of $\mathrm{N}$ storage in grasses. Indeed, uptake of $\mathrm{N}$ by mosses may explain the lack of increased vascular plant net primary productivity (NPP) in response to grazing that was observed in studies in Svalbard (Poa arctica; Bakker and Loonen 1998) and on Bylot Island (Eriophorum scheuchzeri and Dupontia fisheri; Gauthier et al. 1995). These studies contrast findings by Hik and Jefferies 1990 who did observe an increase in NPP of Puccinellia phryganodes with grazing in salt marshes where moss is not a dominant part of the vegetation; however, the difference in response to herbivory might also be linked species specific traits. Absorption of $\mathrm{N}$ from faeces by mosses might be particularly important in the Arctic where low $\mathrm{N}$ availability limits vascular plant growth (Shaver and Chapin 1980; Press et al. 1998; LeBauer and Treseder 2008) and mosses form a large component of the vegetation across the region. Therefore, the applicability of the grazing optimisation model, whereby herbivores increase the productivity of the grazed area, might be reduced in habitats dominated by moss mats that reduce nutrient return to the preferred forage species which is important for regrowth (Hik and Jefferies 1990). We speculate that this may be particularly important in vegetation with thicker moss mats, as typical of arctic fresh-water wet habitats that are preferentially utilised by geese across large parts of their circumpolar range (Prop et al. 1984; Drent et al. 1998; Speed et al. 2009).

Acknowledgments This work was funded by the European Commission Framework 5 grant no: EVK2-CT-2002-00145 (FRAGILE). We are grateful to the University Centre on Svalbard (UNIS) for logistical support and the FRAGILE team for help during the field work campaign, in particular Dr Elisabeth Cooper for providing plant cover data and Richard Ubels for carrying out the collection of goose faeces in 2003. The work of Dr D. Kuijper on the writing of the manuscript has been supported by a Marie Curie Transfer of Knowledge Fellowship BIORESC of European Community's Sixth Framework Programme under contract number MTKD-CT-2005-029957. The experiments carried out within this project comply with the Norwegian laws under which Svalbard is governed. 
Open Access This article is distributed under the terms of the Creative Commons Attribution Noncommercial License which permits any noncommercial use, distribution, and reproduction in any medium, provided the original author(s) and source are credited.

\section{References}

Audet B, Gauthier G, Levesque E (2007) Feeding ecology of greater snow goose goslings in mesic tundra on Bylot Island, Nunavut, Canada. Condor 109:361-376

Bakker C, Loonen M (1998) The influence of goose grazing on the growth of Poa arctica: overestimation of overcompensation. Oikos 82:459-466

Bazely DR, Jefferies RL (1985) Goose faeces-a source of nitrogen for plant-growth in a grazed salt-marsh. J Appl Ecol 22:693-703

Bazely DR, Jefferies RL (1986) Changes in the composition and standing crop of salt-marsh communities in response to the removal of a grazer. J Ecol 74:693-706

Billings SA, Richter DD (2006) Changes in stable isotopic signatures of soil nitrogen and carbon during 40 years of forest development. Oecologia 148:325-333

Brooker R, Van der Wal R (2003) Can soil temperature direct the composition of high arctic plant communities? J Veg Sci 14:535-542

Cadieux MC, Gauthier G, Hughes RJ (2005) Feeding ecology of Canada geese (Branta canadensis interior) in sub-arctic inland tundra during brood-rearing. Auk 122:144-157

DeAngelis DL (1992) Population and community biology series 9. Dynamics of nutrient cycling and food webs. Chapman and Hall, London, UK

Drent RH, van der Wal R (1999) Cyclic grazing in vertebrates and the manipulation of the food resource. In: Olff H, Brown VK, Drent RH (eds) Herbivores: between plants and predators. Blackwell Science, Oxford, pp 271-299

Drent RH, Black JM, Loonen MJJE, Prop J (1998) Barnacle geese Branta leucopsis on Nordenskiöldkysten, western Spitsbergenthirty years from colonisation to saturation. Norsk Polarinst Skri 200:105-114

Floate MJS (1970) Decomposition of organic materials from hill soils and pastures Part 4. The effects of moisture content on the mineralization of carbon nitrogen and phosphorus from plant materials and sheep faeces. Soil Biol Biochem 2:275-283

Frank A, Evans RD (1997) Effects of native grazers on grassland N cycling in Yellowstone national park. Ecology 78:2238-2248

Gauthier G, Hughes RJ, Reed A, Beaulieu J, Rochefort L (1995) Effect of grazing by greater snow geese on the production of graminoids at an arctic site (Bylot Island, NWT, Canada). J Ecol 83:653-664

Gauthier G, Bety J, Giroux JF, Rochefort L (2004) Trophic interactions in a high arctic snow goose colony. Integr Comp Biol 44:119-129

Gornall JL, Jonsdottir IS, Woodin SJ, Van der Wal R (2007) Arctic mosses govern below-ground environment and ecosystem processes. Oecologia 153:931-941

Gornall JL, Woodin SJ, Jónsdóttir IS, Van der Wal R (2009) Herbivore impacts to the moss layer determines tundra ecosystem response to grazing and warming. Oecologia 161:747-758

Hik DS, Jefferies RL (1990) Increases in the net aboveground primary production of a salt-marsh forage grass-a test of the predictions of the herbivore-optimization model. J Ecol 78:180-195

Hwang YT, Millar JS, Longstaffe FJ (2007) Do $\delta^{15} \mathrm{~N}$ and $\delta^{13} \mathrm{C}$ values of feces reflect the isotopic composition of diets in small mammals? Can J Zool 85:388-396
Jensen RA, Madsen J, O'Connell M, Wisz MS, Tommervik H, Mehlum F (2008) Prediction of the distribution of Arctic-nesting pink-footed geese under a warmer climate scenario. Glob Change Biol 14:1-10

Kerbes RH, Kotanen PM, Jefferies RL (1990) Destruction of wetland habitats by lesser snow geese-a keystone species on the west coast of Hudson Bay. J Appl Ecol 27:242-258

Kotanen PM (2002) Fates of added nitrogen in freshwater arctic wetlands grazed by snow geese: the role of mosses. Arct Antarct Alp Res 34:219-225

Kramer MG, Sollins P, Sletten RS, Swart PK (2003) N isotope fractionation and measures of organic matter alteration during decomposition. Ecology 84:2021-2025

Kuijper DPJ, Ubels R, Loonen MJJE (2009) Density dependent switches in diet; a likely mechanism for negative feedbacks on goose population increase? Polar Biol 32:1789-1803

LeBauer DS, Treseder KK (2008) Nitrogen limitation of net primary productivity in terrestrial ecosystems is globally distributed. Ecology 89:371-379

Lee YI, Lim HS, Yoon HI (2009) Carbon and nitrogen isotope composition of vegetation on King George Island, maritime Antarctic. Polar Biol 32:1607-1615

Malmer N, Albinsson C, Svensson BM, Wallen B (2003) Interferences between Sphagnum and vascular plants: effects on plant community structure and peat formation. Oikos 100:469-482

Marsh AS, Arnone JA, Bormann BT, Gordon JC (2000) The role of Equisetum in nutrient cycling in an Alaskan shrub wetland. J Ecol 88:999-1011

McNaughton SJ (1979) Grazing as an optimization process: grass ungulate relationships in the Serengeti. Am Nat 113:691-703

McNaughton SJ (1984) Grazing lawns-animals in herds, plant form, and coevolution. Am Nat 124:863-886

Ngai JT, Jefferies RL (2004) Nutrient limitation of plant growth and forage quality in Arctic coastal marshes. J Ecol 92:1001-1010

Olff H, Ritchie ME (1998) Effects of herbivores on grassland plant diversity. Trends Ecol Evol 13:261-265

Olofsson J, Stark S, Oksanen L (2004) Reindeer influence on ecosystem processes in the tundra. Oikos 105:386-396

Press MC, Potter JA, Burke MJW, Callaghan TV, Lee JA (1998) Responses of a subarctic dwarf shrub heath community to simulated environmental change. J Ecol 86:315-327

Prins HHT, Ydenberg RC, Drent RH (1980) The interaction of Brent geese Branta bernicla and sea plantain Plantago maritima during spring staging-field observations and experiments. Acta Bot Neerl 29:585-596

Prop J, van Eerden MR, Drent RH (1984) Reproductive success of the Barnacle goose Branta leucopsis in relation to food exploitation on the breeding grounds, western Spitsbergen. Norsk Polarinst Skri 181:87-117

Shaver GR, Chapin FS (1980) Response to fertilization by various plant-growth forms in an Alaskan tundra-nutrient accumulation and growth. Ecology 61:662-675

Sjögersten S, van der Wal R, Woodin SJ (2008) Habitat type determines herbivory controls over $\mathrm{CO}_{2}$ fluxes in a warmer arctic. Ecology 89:2103-2116

Speed JDM, Woodin SJ, Tommervik H, Tamstorf MP, van der Wal R (2009) Predicting habitat utilization and extent of ecosystem disturbance by an increasing herbivore population. Ecosystems 12:349-359

Stark S, Grellmann D (2002) Soil microbial responses to herbivory in an arctic tundra heath at two levels of nutrient availability. Ecology 83:2736-2744

Tye AM, Young SD, Crout NMJ, West HM, Stapleton LM, Poulton PR, Laybourn-Parry J (2005) The fate of ${ }^{15} \mathrm{~N}$ added to high Arctic tundra to mimic increased inputs of atmospheric nitrogen released from a melting snowpack. Glob Change Biol 11:1640-1654 
Van der Graaf AJ, Stahl J, Bakker JP (2005) Compensatory growth of Festuca rubra after grazing: can migratory herbivores increase their own harvest during staging? Funct Ecol 19:961-969

Van der Wal R (2005) Plant-animal interactions. In: Nuttall M (ed) Encyclopedia of the Arctic. Routledge, New York, pp 16491650

Van der Wal R, Brooker RW (2004) Mosses mediate grazer impacts on grass abundance in arctic ecosystems. Func Ecol 18:77-86

Van der Wal R, Hessen DO (2009) Analogous aquatic and terrestrial food webs in the high Arctic: the structuring force of a harsh climate. Perspect Plant Ecol 11:231-240

Van der Wal R, Bardgett RD, Harrison KA, Stien A (2004) Vertebrate herbivores and ecosystem control: cascading effects of faeces on tundra ecosystems. Ecography 27:242-252

Varo N, Amat JA (2008) Differences in food assimilation between two coot species assessed with stable isotopes and particle size in faeces: linking physiology and conservation. Comp Biochem Phys A 149:217-223

Wada E, Shibata R, Torii T (1981) N-15 Abundance in Antarcticaorigin of soil nitrogen and ecological implications. Nature 292:327-329

Wisz MS, Tamstorf MP, Madsen J, Jespersen M (2008) Where might the western Svalbard tundra be vulnerable to pink-footed goose (Anser brachyrhynchus) population expansion? Clues from species distribution models. Divers Distrib 14:26-37

Zacheis A, Ruess RW, Hupp JW (2002) Nitrogen dynamics in an Alaskan salt marsh following spring use by geese. Oecologia 130:600-608

Zimov SA, Chuprynin VI, Oreshko AP, Chapin FS, Reynolds JF, Chapin MC (1995) Steppe-tundra transition: a herbivore-driven biome shift at the end of the Pleistocene. Am Nat 146:765-794 